\title{
Identification of N-myc Regulatory Regions Involved in Embryonic Expression
}

\author{
JEAN CHARRON, JEAN-FRANÇOIS GAGNON, AND JEAN-FRANÇOIS CADRIN-GIRARD \\ Center of Research on Cancer, University Laval, CHUQ, L'Hôtel-Dieu de Québec, \\ Québec, Québec G1R 2J6, Canada
}

\begin{abstract}
Our knowledge on the regulation of the N-myc protooncogene expression comes mostly from in vitro studies. Very few in vivo analyses have been performed to identify the regulatory elements involved in N-myc developmental expression. In the present study, we defined DNA regions required for the regulated expression of $\mathrm{N}-m y c$ during early embryogenesis. We showed that the expression of $\mathrm{N}-m y c$ driven by the human $\mathrm{N}-m y c$ sequences previously described to control N-myc expression in appropriate cell types in vitro cannot rescue the mouse $\mathrm{N}-m y c$ mutant phenotype, suggesting that regulatory elements necessary for $\mathrm{N}-m y c$ embryonic expression were missing. To identify the regulatory DNA regions involved in $\mathrm{N}-m y c$ expression, transgenic mouse lines carrying $\mathrm{N}-m y c / l a c \mathrm{Z}$ reporter constructs were generated. $\beta$-Galactosidase staining analysis at different stages of gestation revealed that $>16 \mathrm{~kb}$ of mouse N-myc genomic sequences are required to recapitulate the entire spatiotemporal
\end{abstract}

\section{ABSTRACT}

expression pattern of the endogenous N-myc gene between embryonic $\mathrm{d} 8.5$ and 11.5. This observation supported the notion that the sequences previously identified by in vitro assays were not sufficient to reproduce the N-myc embryonic expression pattern. However, regulatory elements that can direct specific expression in the visceral arches, the limb buds, the CNS, and the dorsal root ganglia are included into the mouse $\mathrm{N}-m y c$ genomic sequences tested. Altogether, these findings indicated that the regulation of the spatiotemporal expression pattern of N-myc during development necessitates multiple regulatory DNA elements. (Pediatr Res 51: 48-56, 2002)

E, embryonic day

\section{Abbreviations}

DRG, dorsal root ganglia
$\mathrm{N}-m y c$ gene is a member of the myc gene family, which encodes highly related transcription factors that share many structural and biochemical functions (1-5). c-myc, N-myc, and $\mathrm{L}-m y c$ genes are the best-characterized members of this family. These three myc members are involved in the initiation and progression of naturally occurring neoplasms. Their tumorigenic potential has also been demonstrated by transformation assays both in vitro and in vivo (6). Most likely the tumorigenic capacities of both c-Myc and N-Myc reside in part in their ability to drive cells into the cell cycle $(7,8)$.

The N-myc gene is associated with specific tumors, such as neuroblastoma, retinoblastoma, and small cell lung carcinoma. The activation of $\mathrm{N}-m y c$ in these various neoplasms always leads to inappropriate and elevated expression of a gene encoding an apparently normal Myc protein (9). Gene amplification is the main mechanism that leads to N-myc overexpression in tumor cells $(10-12)$. However, among the most

Received April 10, 2001; accepted July 11, 2001

Correspondence and reprint requests: Jean Charron, Ph.D., Centre de recherche en cancérologie de l'Université Laval, CHUQ, L'Hôtel-Dieu de Québec, 9, rue McMahon, Québec, QC, G1R 2J6 Canada; e-mail: jean.charron@crhdq.ulaval.ca

Supported by a Cancer Research Society Inc. grant to J.C. J.-F.G. held a studentship from the Fonds pour la Formation de Chercheurs et l'Aide à la Recherche. aggressive neuroblastomas, a class exists in which no gene amplification is detected. Thus, gene amplification cannot account for the high level of N-myc mRNA in this subset of tumors $(13,14)$. Therefore, other mechanisms might be involved in the deregulation of N-myc expression, such as modification of $\mathrm{N}-m y c$ regulatory sequences or deregulation of $\mathrm{N}-m y c$ transcriptional regulators.

$\mathrm{N}-m y c$ is involved in organogenesis. Homozygous null Nmyc mutant mice die at E11.5. In mutant embryos, defects such as reduced size and decreased cellularity are present primarily in tissues and organs that express high levels of N-myc transcripts, including the cranial and spinal ganglia, mesonephros, lung, liver, and gut (15-21). In a similar way, c-myc homozygous mutant embryos die before E10.5, and they also exhibit a marked embryo size reduction and a generalized delay in the development of many organs $(22,23)$. Overlapping expression pattern and redundant functional properties among myc family members was proposed to explain survival of individual myc family gene mutant mice through early embryogenesis (15-17, 22). More recently, Malynn et al. (3) have shown, by replacing the endogenous c-myc coding sequences by the N-myc ones, that N-Myc can complement c-myc functions in cell growth and differentiation during mouse development, suggesting that 
the distinct functions of both genes reside in a large extent in their specific expression pattern.

The expression patterns of the c-myc and $\mathrm{N}-m y c$ genes are distinct, albeit overlapping, during early embryogenesis. Both genes are expressed at preimplantation stages, and their expression profiles diverge with advancing development. c-myc gene is widely expressed in tissues and organs in proliferation, whereas $\mathrm{N}-m y c$ expression is restricted to a limited number of tissues and organs and it is not necessarily associated with cells in mitosis (24-30). At E9.5, N-myc is highly expressed in the CNS including the mesencephalon, prosencephalon, and neural tube (28). At this stage, $\mathrm{N}-m y c$ expression is also detected in neural crest-derived tissues such as the facial primordia, the visceral arches, and the DRG, as well as in mesodermal derivatives including the caudal part of the somites and the sclerotomes derived from it, the mesonephric tubules, and the limb buds. N-myc is also expressed in a complementary fashion with c-myc in some tissues, such as the early gut, brain, lung, and kidney $(17-19,26,31)$. In tissues in which N-myc and c-myc are coexpressed, c-myc is often associated with rapidly proliferating cells, whereas $\mathrm{N}-m y c$ persists through cellular differentiation. These different expression patterns suggest specific roles for c-myc and N-myc. Cis-acting sequences involved in the regulation of $\mathrm{N}-m y c$ gene expression have been identified mainly from in vitro assays using N-myc promoterreporter constructs introduced into cells from different species (32-39). Major regulatory elements are located within sequences $2 \mathrm{~kb}$ upstream of the transcription initiation site and in the first exon and intron of the gene. Transgenic mice analyses have suggested that genomic fragments containing these regulatory elements are able to direct $\mathrm{N}-m y c$ expression in newborn and adult tissues in a manner that parallels the endogenous N-myc gene $(34,38,40)$. However, these studies have not shown whether these sequences are sufficient to recapitulate the embryonic spatiotemporal expression profile of the gene.

To tackle this problem, we have used two approaches. First, we attempted to complement the embryonic lethal phenotype of the N-myc mutant mice with a human transgene containing previously described regulatory elements $(15,40)$. The complete absence of rescue suggested that the transgene was not adequately expressed during mouse development. Second, we initiated the identification of regulatory regions implicated in mouse embryonic expression of the N-myc gene. Transgenic mice carrying the bacterial lac $\mathrm{Z}$ gene under the control of mouse N-myc genomic fragments were generated. Although none of the transgenes recapitulated the entire expression pattern of N-myc during early development, some of the constructs directed the expression to a subset of N-myc expression sites. Our findings indicated that a combination of distal and proximal regulatory elements is required for the proper spatial and temporal expression of $\mathrm{N}-m y c$ during embryogenesis.

\section{METHODS}

Construction of $\mathrm{N}$-myc/lac $Z$ transgenes. The mouse $\mathrm{N}-m y c$ genomic sequences contained in the N-myc 40, N-myc 41X, and $\mathrm{N}-m y c 41 \mathrm{~S}$ transgenes were derived from a normal mouse DNA genomic library. All the constructs contain the 7.7-kb
EcoRI fragment described in DePinho et al. (41). This fragment was previously modified by the insertion of the neo gene into the second exon of $\mathrm{N}-m y c$, which generated the vector pJC7/N-myc-P (42). To construct the plasmid N-myc 40, the neo sequences of pJC7/N-myc-P were replaced by lac Z sequences. The BamHI-HindIII lac $\mathrm{Z}$ fragment obtained from pCH110 (Pharmacia, Baie d'Urfé, Québec, Canada) was blunted using the $\mathrm{T}_{4}$ DNA polymerase and cloned into the

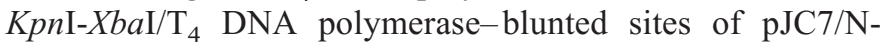
$m y c-\mathrm{P}$ to produce $\mathrm{pJC} 40$. The $\mathrm{N}-m y c 40$ fragment was derived from the pJC40 construct by a TthIII1- SalI digestion.

The transgenes N-myc 41X and N-myc 41S were obtained from pJC21, a pUC18 plasmid containing a 16-kb SalI N-myc genomic fragment that extends from $-4.4 \mathrm{~kb}$ to $+11.6 \mathrm{~kb}$, the Sall sites deriving from the phage clone. pJC41 was obtained by introducing the RsrII-NruI N-myc/lacZ fragment of pJC40 into the RsrII-NruI unique N-myc genomic sites of pJC21. The pJC41 construct was digested with either $X b a \mathrm{I}$ or SalI to generate the $\mathrm{N}-m y c \quad 41 \mathrm{X}$ and $\mathrm{N}-m y c$ 41S transgenes, respectively.

Production and identification of transgenic mice. All transgenes were separated from the vector sequences after migration on agarose gel before being microinjected. N-myc 40 and $\mathrm{N}-m y c 41 \mathrm{X}$ fragments were isolated from the agarose using the glass powder-NaI DNA isolation procedure (43). N-myc 41S fragment was isolated from the agarose by electro-elution and phenol extraction as described in Hogan et al. (44). Transgenic lines were obtained by microinjection of the purified fragments into the pronuclei of fertilized eggs derived from $(\mathrm{C} 57 \mathrm{Bl} / 6 \times$ CBA) F1 hybrid intercrosses as described in Larochelle et al. (45). All animal experiments were performed according to guidelines established by the Canadian Council of Animal Care, and protocols were approved by the Animal Care Committee of Université Laval.

Transgenic mice were identified by Southern blot analysis of DNA extracted from mouse tail biopsy at 2 to $3 \mathrm{wk}$ of age. Purified DNA was digested with EcoRI, fractionated by electrophoresis through $0.8 \%$ agarose gels, and blotted onto Qiabrane membrane (QIAGEN, Mississauga, Ontario, Canada). The filters were hybridized with a random-labeled ClaIEcoRI third exon N-myc probe (42). The DNA of each transgenic founder was analyzed to verify the copy number and the integrity of the inserted construct. Southern blot analysis was performed using appropriate restriction sites and probes. None of the constructs in the transgenic lines that show X-gal staining was rearranged. The copy number of the transgene sequences varied from 2 to $>100$ copies, organized in a head-to-tail configuration at a single integration site (data not shown).

Whole-mount in situ hybridization analysis. The wholemount in situ hybridization protocol was based essentially on that of Larochelle et al. (45). The 817-bp PvuII-ClaI murine cDNA fragment of N-myc-containing sequences from the second exon was used as a template for synthesizing the digoxigenin UTP-labeled riboprobe.

$\boldsymbol{\beta}$-Galactosidase staining. Transgenic males were bred with nontransgenic $(\mathrm{C} 57 \mathrm{Bl} / 6 \times \mathrm{CBA}) \mathrm{F} 1$ hybrid females to generate timed matings. The day of the vaginal plug was considered 
as E0.5. Embryos were collected at various stages between E8.5 and E11.5, and yolk sacs were used to determine the genotype of the embryos. Embryos were fixed in ice-cold $0.25 \%$ glutaraldehyde prepared in $0.1 \mathrm{M}$ phosphate buffer, $\mathrm{pH}$ 7.0, $2 \mathrm{mM} \mathrm{MgCl}_{2}$, and $5 \mathrm{mM}$ EGTA for $12 \mathrm{~min}$ for E8.5, 15 $\mathrm{min}$ for E9.5 and E10.5, and $30 \mathrm{~min}$ for E11.5. Fixation was followed by three 20-min rinses at room temperature in $0.1 \mathrm{M}$ phosphate sodium buffer, $\mathrm{pH} 7.0,2 \mathrm{mM} \mathrm{MgCl}_{2}, 5 \mathrm{mM}$ EGTA, $0.01 \%$ deoxycholic acid (sodium salt), and $0.02 \%$ Nonidet P-40, Sigma, Oakville, Ontario, Canada. Embryos were stained overnight at room temperature in $1 \mathrm{mg} / \mathrm{mL} \mathrm{X-gal} \mathrm{(dissolved} \mathrm{at}$ $20 \mathrm{mg} / \mathrm{mL}$ in dimethyl formamide), $5 \mathrm{mM} \mathrm{K}_{3} \mathrm{Fe}(\mathrm{CN})_{6}, 5 \mathrm{mM}$ $\mathrm{K}_{4} \mathrm{Fe}(\mathrm{CN})_{6}, 1 \mathrm{mM}$ spermidine, and $0.2 \mathrm{mM} \mathrm{NaCl}$ prepared in the above rinse solution. After staining, tissues were briefly rinsed in $0.1 \mathrm{M}$ phosphate sodium buffer, $\mathrm{pH} 7.0$, and then progressively dehydrated by successive transfers in graded alcohol. For photography, whole embryos were clarified with benzyl benzoate-benzyl alcohol (2:1) for $30 \mathrm{~min}$ to $2 \mathrm{~h}$ depending on the size of the specimen.

Histologic analysis. Embryos were dissected from the visceral yolk sac, fixed for $16 \mathrm{~h}$ in ice-cold $4 \%$ paraformaldehyde, dehydrated by successive transfers in graded alcohol and xylene, and embedded in paraffin as previously described (15). Six-micrometer sections were stained with Harris hematoxylin and eosin following standard procedures.

\section{RESULTS}

hN1 transgene cannot rescue the $N$-myc mutant phenotype. Zimmerman et al. (40) have described a mouse transgenic line containing regulatory elements identified by in vitro assays that apparently direct normal expression of a human transgene in newborn and adult tissues. This transgenic line was termed $\operatorname{TgN}(\mathrm{hN} 1)$. To determine whether this transgene can reproduce $\mathrm{N}-m y c$ early embryonic expression, the $\mathrm{TgN}(\mathrm{hN} 1)$ mouse line was bred with the $\mathrm{N}-m y c$ mutant mouse line $\left(\mathrm{N}-m y c^{+-}\right)$to rescue the $\mathrm{N}-m y c$ mutant phenotype (15). N-myc $c^{-1-}$ $\operatorname{TgN}(\mathrm{hN} 1)^{+/-}$mice were generated by breeding $\mathrm{N}-m y c^{+/-}$ females to $\mathrm{N}-m y c^{+/-} \operatorname{TgN}(\mathrm{hN} 1)^{+/+}$males, with an expected ratio of embryos or mice being $1 \mathrm{~N}-m y c^{+/+} \mathrm{TgN}(\mathrm{hN} 1)^{+/-}: 2$ $\mathrm{N}-m y c^{+/-} \operatorname{TgN}(\mathrm{hN} 1)^{+/-}: 1 \mathrm{~N}-m y c^{-/-} \operatorname{TgN}(\mathrm{hN} 1)^{+/-}$.

The genotype of the resulting progeny was determined by Southern blot analysis using specific human and mouse N-myc probes as previously described $(15,40)$. Of 59 live offspring obtained between $1 \mathrm{~d}$ and $3 \mathrm{wk}$ after birth, none was found homozygous for the $\mathrm{N}-m y c$ mutation, indicating that the lethal phenotype associated with the $\mathrm{N}-m y c$ mutation was not rescued by the $\operatorname{TgN}(\mathrm{hN} 1)$ transgene (Table 1). To determine whether the $\mathrm{TgN}(\mathrm{hN} 1)$ transgene can partially rescue the N-myc muta- tion, $\mathrm{N}-m y c^{+/-} \operatorname{TgN}(\mathrm{hN} 1)^{+/+}$males were mated with $\mathrm{N}-m y c^{+/-}$females, and the females were killed at different times of gestation. The embryos were dissected from the visceral yolk sac, and their genotype was determined. At $\mathrm{E} 10.5$, the ratio of $\mathrm{N}-m y c^{+/+} \mathrm{TgN}(\mathrm{hN} 1)^{+/-}: \mathrm{N}-m y c^{+/-}$ $\operatorname{TgN}(\mathrm{hN} 1)^{+/-}: \mathrm{N}-m y c^{-/-} \operatorname{TgN}(\mathrm{hN} 1)^{+/-}$embryos was $1: 2: 1$ as expected (Table 1). However, at E12.5, all the $\mathrm{N}-m y c^{-1-}$ $\operatorname{TgN}(\mathrm{hN} 1)^{+/-}$embryos as determined by genotype were found dead or in the process of resorption. Histopathologic analysis of E10.5 N-myc $c^{-1-} \operatorname{TgN}(\mathrm{hN} 1)^{+/-}$embryos revealed that they present the same defects as the ones previously described for $\mathrm{N}-m y c^{-1-}$ mutant embryos (15). For instance, the heart of $\mathrm{N}-m y c^{-/-} \operatorname{TgN}(\mathrm{hN} 1)^{+/-}$embryos was underdeveloped, and analysis of successive sections indicated that it retained the S-shape more typical of an earlier developmental stage (Fig. $1 A$ ). The pericardial cavity was empty owing to the underdevelopment of the heart. Observation of transverse sections at the level of the brain also showed the size reduction of the cranial and spinal ganglia, as well as irregularities and decreased cellularity in the neural ectoderm of the telencephalon and myelencephalon (Fig. 1B; data not shown). Therefore, the presence of the $\mathrm{TgN}(\mathrm{hN} 1)$ transgene could not complement the $\mathrm{N}-m y c$ phenotype, suggesting either that the $\operatorname{TgN}(\mathrm{hN} 1)$ transgene was unable to recapitulate the endogenous expression pattern or reach the mRNA levels of the endogenous N-myc gene during early embryogenesis. Although the possibility exists that the human N-Myc protein may not have the same properties as the mouse one, we hypothesized that the human $\mathrm{N}-m y c$ transgene tested lacks essential regulatory elements for appropriate $\mathrm{N}-m y c$ expression during early development. To identify the cis-acting sequences required to reproduce the endogenous embryonic expression pattern of N-myc, transgenic lines containing mouse $\mathrm{N}-m y c$ genomic sequences linked to a lac Z reporter gene were produced.

Expression of $\mathrm{N}$-myc gene at mid-gestation. To determine whether the N-mycllac $\mathrm{Z}$ transgenes analyzed in the present study can recapitulate the $\mathrm{N}-m y c$ endogenous expression pattern, we performed whole-mount in situ hybridization using a probe derived from the second exon of the murine N-myc cDNA. This probe was shown to specifically reveal N-myc transcripts in E12.5 lung epithelium as expected (20) (data not shown). In E9.5 embryos, N-myc expression was detected in the CNS, the facial primordia, the branchial arches, the limb buds, and the somites as previously described by in situ hybridization on section (Fig. 2A) (28). A faint staining of the myocardium of the cardiac ventricle could be observed. In contrast, $\mathrm{N}-m y c$ expression in the mandibular and the hyoid arches was clearly defined. At E11.5, signal was still

Table 1. Viability of $N-m y c^{-/-} / \operatorname{TgN}(h N 1)^{+/-}$embryos

\begin{tabular}{|c|c|c|c|c|c|}
\hline \multirow[b]{2}{*}{ Age* } & \multirow{2}{*}{$\begin{array}{c}\text { Number of } \\
\text { litters }\end{array}$} & \multirow{2}{*}{$\begin{array}{c}\text { Number of } \\
\text { pups }\end{array}$} & \multicolumn{3}{|c|}{ Genotype of alive embryos or mice $\mathrm{TgN}(\mathrm{hN} 1)^{+/-}$} \\
\hline & & & $\mathrm{N}-m y c^{+/+}$ & $\mathrm{N}-m y c^{+/-}$ & $\mathrm{N}-m y c^{-1-}$ \\
\hline E10.5 & 2 & 17 & 5 & 8 & 4 \\
\hline D1-21 & 11 & 59 & 19 & 40 & 0 \\
\hline
\end{tabular}

* D1-21 represents a range between 1 and $21 \mathrm{~d}$ of age in the pups.

$\dagger$ Four dead embryos in the process of being resorbed were genotyped $\mathrm{N}-m y c^{-1-}$. One embryo was not genotyped. 
A

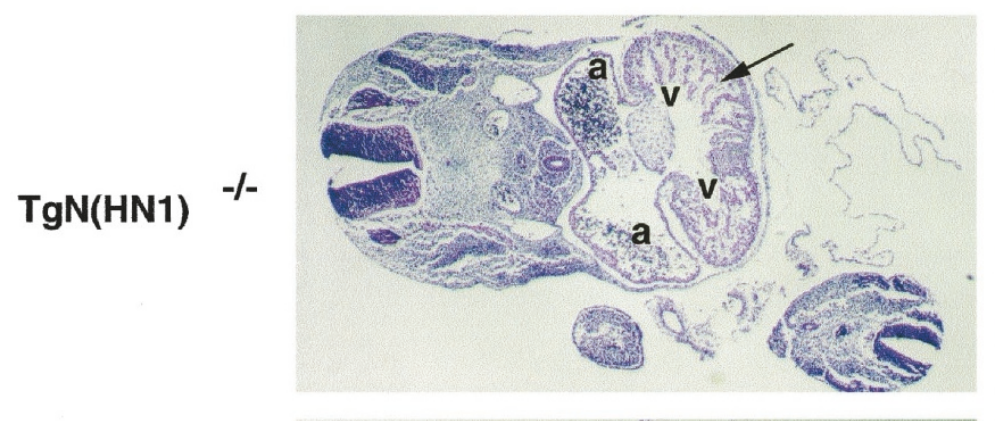

$\mathrm{N}-\mathrm{myc}^{+/+}$

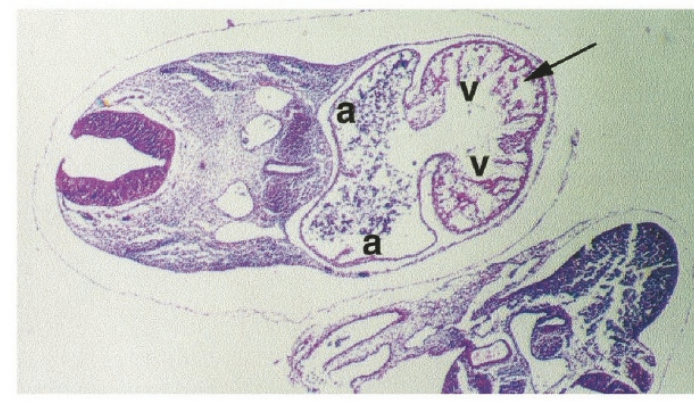

B

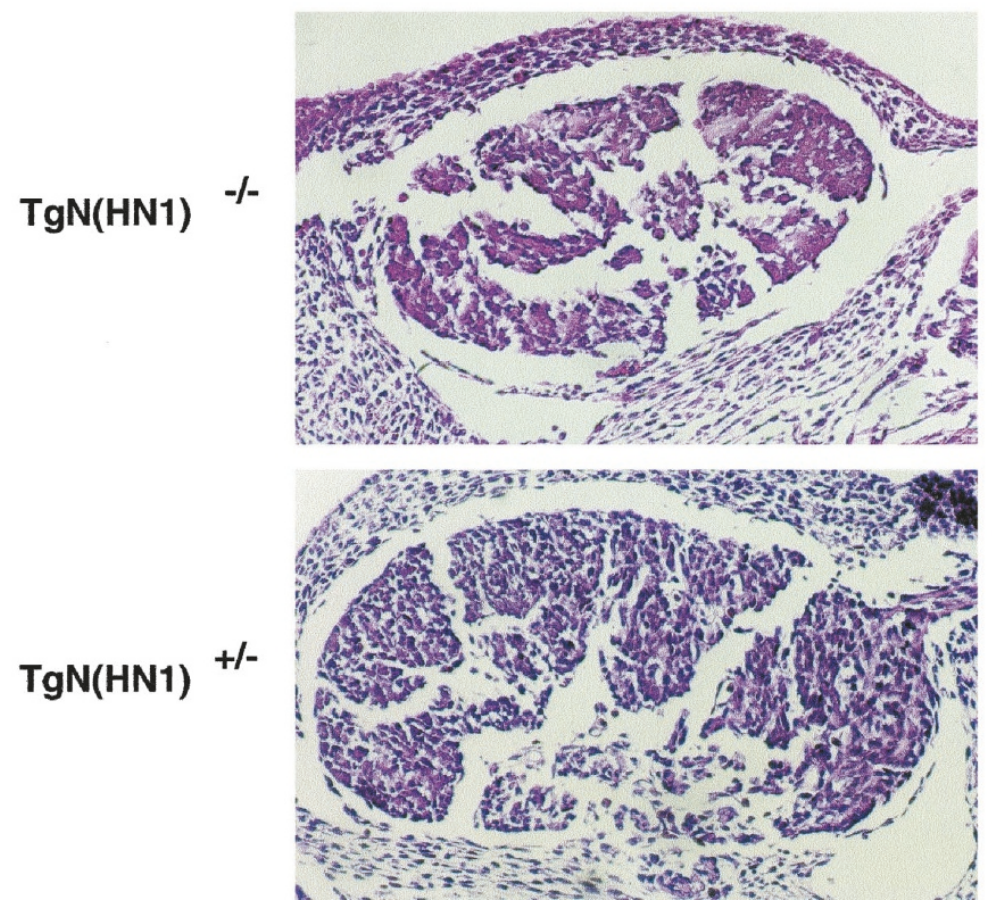

$\mathrm{N}-\mathrm{myc}^{-1-}$
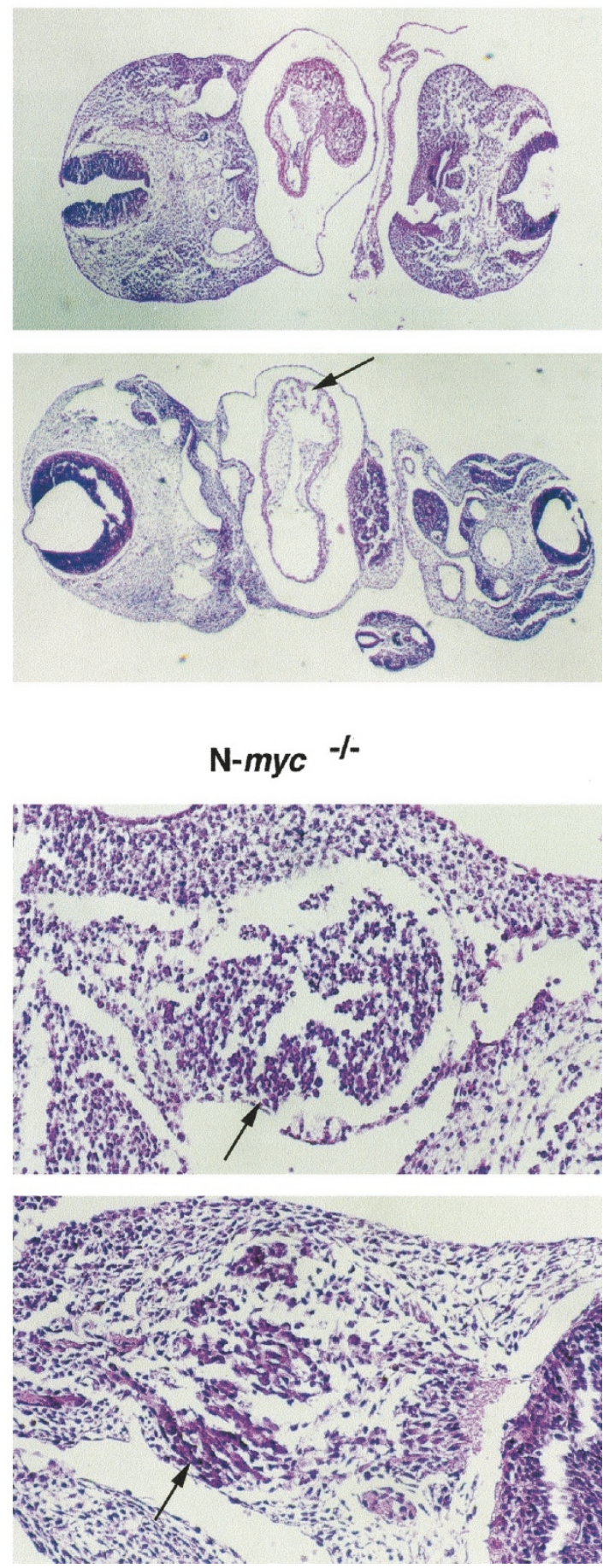

Figure 1. Comparison of heart and cranial development between wild-type and mutant embryos in presence or absence of the TgN(hN1) transgene. $A$, transverse sections through the heart of E10.5 wild-type and homozygous N-myc mutant embryos complemented with the TgN(hN1) transgene are shown. Similar transverse sections of wild-type and homozygous mutant $\mathrm{N}-m y c$ embryos lacking the transgene are presented for comparison. In contrast to wild-type specimens, $\mathrm{N}-m y c^{-1-}$ hearts were not divided into atrial $(a)$ and ventricular $(v)$ chambers, and the trabeculation of the ventricles was greatly reduced (arrows). B, comparative morphology of the ganglion of trigeminal nerve $\mathrm{V}$ from transverse brain sections of wild-type and homozygous mutant carrying or not the $\mathrm{TgN}(\mathrm{hN} 1)$ transgene. Reduction in size or cellularity, and disorganization of the structure were observed in both mutant specimens (arrows). Original magnification $A$ and $B, \times 20$ and $\times 50$, respectively.

observed in the CNS, the branchial arches, and the somites located in the caudal region of the embryo. Expression in the DRG as well as in the cranial ganglia was detected, but the highest level of expression was in the proliferating zone of the limb bud with a proximal-distal gradient of labeling (Fig. 2B). 

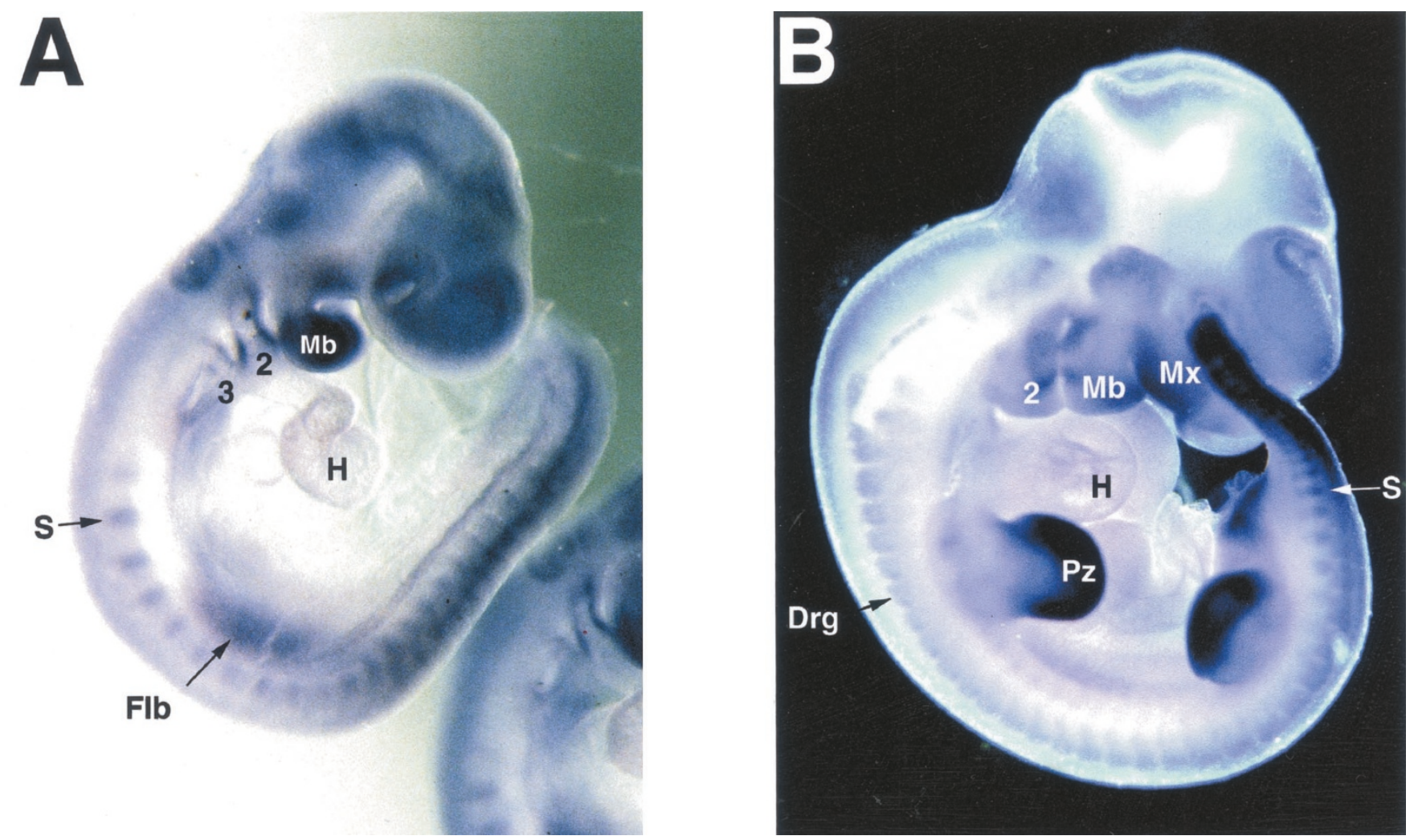

Figure 2. Expression pattern of the endogenous N-myc gene. Whole-mount in situ hybridization was performed on embryos at $9.5(A)$ and at $11.5(B)$ day of gestation. At E9.5, expression was detected in the CNS, the somites $(S)$, the forelimb buds $(F l b)$, the heart $(H)$ and the branchial arches. The first branchial arches are indicated mandible $(M b)$, second and third branchial arches $(2,3)$. At E11.5, N-myc expression remained in the CNS and in the somites. N-myc transcripts were also detected in the dorsal root ganglia $(D R G)$, the progressive zone of the limbs $(P z)$, and in the maxillary $(M x)$.

Partial reconstitution of $N$-myc embryonic expression pattern in transgenic mice. Zimmerman et al. (40) have shown that a transgene containing a $7.7-\mathrm{kb}$ genomic fragment of the mouse $\mathrm{N}-m y c$ gene, extending from $-1.7 \mathrm{~kb}$ to $+6.0 \mathrm{~kb}$, was able to direct expression in mouse newborn brain and kidney, albeit at a lower expression levels than the endogenous N-myc gene. This fragment contains the regions described to exert positive and negative effects on the mouse N-myc promoter by in vitro assays $(32-36,38,46)$. Our rescue experiments with the human $\mathrm{N}-m y c$ transgene, which contains more upstream and downstream sequences than the $7.7-\mathrm{kb}$ mouse genomic fragment, suggested the need for more cis-acting sequences to correctly direct the spatiotemporal expression profile of N-myc gene during mouse early embryogenesis. We first tested whether the 7.7-kb mouse genomic fragment can reproduce the $\mathrm{N}-m y c$ developmental expression pattern by producing transgenic animals carrying a chimeric construct that contains this $7.7-\mathrm{kb}$ mouse genomic fragment fused in frame to lac $\mathrm{Z}$ sequences. The lac $\mathrm{Z}$ sequences were inserted immediately downstream of the initiation codon of the N-Myc protein in the $\mathrm{N}-m y c$ second exon, replacing 300 bp of N-myc coding sequences (construct N-myc 40; Fig. 3). The deletion of the $\mathrm{N}-m y c$ coding sequences, which are not expected to contain any regulatory element, should not affect N-myc gene regulation. Of seven independent transgenic mouse lines established, three displayed embryonic transgene expression, including two with identical X-gal staining pattern (Fig. 4, $A-D$ ).
$\beta$-Galactosidase activity of the $\mathrm{N}-m y c 40$ transgene was monitored in embryos from E8.5 to E11.5, as the expression domain of $\mathrm{N}-m y c$ is clearly defined at these stages. Moreover, these embryonic ages include the time of death of the N-myc homozygous mutant embryos $(15,28-30)$. At E8.5, expression was detected in the first branchial arch, and it remained restricted to these structures at E9.5 and E10.5 (Fig. 4, $A-C$ ). At E11.5, $\beta$-galactosidase expression was observed along the CNS with the loss of the specific staining in branchial arches (Fig. 4D). Additional cis-acting sequences were therefore required to recapitulate the appropriate spatiotemporal regulation of N-myc during embryogenesis.

To test this hypothesis, we generated transgenic animals carrying an N-myc/lac Z transgene containing $9.2 \mathrm{~kb}$ of genomic sequences and encompassing the $\mathrm{N}-m y c$ gene from position $-2.2 \mathrm{~kb}$ to position $+7.0 \mathrm{~kb}$ (construct N-myc 41X; Fig. 3). Five transgenic lines were generated, among which three expressed the transgene and showed similar X-gal staining patterns. As for the N-myc 40 transgene, staining was localized in the first branchial arch at E8.5 (Fig. 4E). One day later, transgene expression was detected in branchial arches as well as in limb buds (Fig. 4F). At E10.5 and E11.5, X-gal staining was located in the same structures, but the expression was more restricted. Expression was localized in the apical ectodermal ridge of the limb and it was limited to the anterior region of the mandibular arch (Fig. 4, $G$ and $H$ ). One transgenic line did not show expression in the limb buds, but 
instead, expression in the CNS and DRG was observed at E11.5 (data not shown). Thus, additional 5' and 3' N-myc genomic sequences to the $\mathrm{N}-m y c 40$ transgene revealed the presence of regulatory elements specific to the limb buds.

A longer construct was tested, N-myc 41S, that contained a $16-\mathrm{kb} \mathrm{N}-m y c$ genomic fragment including sequences from position $-4.4 \mathrm{~kb}$ to position $+11.6 \mathrm{~kb}$ (Fig. 3). Four $\mathrm{N}-m y c$ 41S transgenic lines were established, and they all expressed the transgene with an identical pattern of X-gal staining in the branchial arches and limb buds. At E8.5 and E9.5, these lines presented the same expression pattern as the one observed with the $\mathrm{N}-m y c 41 \mathrm{X}$ construct, with expression in the mesodermal tissues of the visceral arches and in the limb buds (Fig. 4, E, F, $I$, and $J$ ). At E10.5, the $\mathrm{N}-m y c 41 \mathrm{~S}$ transgenic lines reproduced the expression pattern observed in the N-myc $41 \mathrm{X}$ lines, but additional expression was seen in the CNS and DRG for two lines (Fig. $4 K$ ). However, staining intensity in the CNS was lower than in the visceral arches and limb buds. One day later, the same pattern was observed with a stronger signal in the CNS and DRG (Fig. 4L). Staining in the DRG was confirmed by sectioning the embryos (data not shown). A construct including $\mathrm{N}-m y c$ genomic sequences from $-8.7 \mathrm{~kb}$ to $+7.0 \mathrm{~kb}$ was also tested in transient transgenics. This construct contained 4.3-kb more $5^{\prime}$ sequences than the longest transgene $\mathrm{N}-m y c$ 41. At E10.5, a similar expression pattern to the N-myc 41 construct ones was observed with staining in the branchial arches and the limbs, indicating that sequences required for the entire N-myc embryonic expression are located in even more $5^{\prime}$ or 3' DNA regions (data not shown).

\section{DISCUSSION}

Regulation of gene expression implies a considerable number of molecular elements, all necessary to obtain a precise modulation of expression. In vitro assays are often used to identify regions implicated in regulation. However, these assays may reproduce partial aspects of the regulation that takes place in vivo. Such in vitro experiments have revealed that correct N-myc expression can be supported by $1 \mathrm{~kb}$ of $5^{\prime}$ flanking sequences and $6 \mathrm{~kb}$ of $3^{\prime}$ flanking sequences of the human N-myc gene. These experiments demonstrated correct expression in human and murine cell lines as well as in mouse newborn and adult tissues (34). In contrast, our analysis using a transgenic approach has revealed that $\mathrm{N}-m y c$ embryonic expression pattern cannot be entirely reconstituted with a similar mouse genomic fragment (N-myc 40). Moreover, $16 \mathrm{~kb}$ of mouse N-myc genomic sequences appears to be insufficient to reproduce the endogenous $\mathrm{N}-m y c$ expression profile during embryogenesis.

Even if the pattern is not entirely reconstituted with the constructs we tested, sequences included in the genomic fragment extending from $-4.4 \mathrm{~kb}$ to $+11.6 \mathrm{~kb}$ contain regulatory elements able to direct expression in the branchial arches, the limb buds, the CNS, and the DRG. The lacZ expression detected in the branchial arches of the N-myc 40 transgenic mice indicated that branchial arch-specific control elements are included in the shortest construct. However, the higher levels of X-gal staining in branchial arches of specimens generated with the N-myc 41X transgene suggest that additional elements might be involved in N-myc branchial arch regulation. Furthermore, CNS expression was observed for all transgenes tested, but because expression in this structure was delayed when compared with endogenous N-myc gene expression, more regulatory sequences are most probably required.

The differences observed in the X-gal staining pattern between transgenes $\mathrm{N}-m y c 40$ and $\mathrm{N}-m y c 41 \mathrm{X}$ suggest that regulatory elements directing $\mathrm{N}-m y c$ expression in the limb buds must be present either in the 5 ' region located between positions $-2.2 \mathrm{~kb}$ and $-1.7 \mathrm{~kb}$, or in the $3^{\prime}$ region in the

A

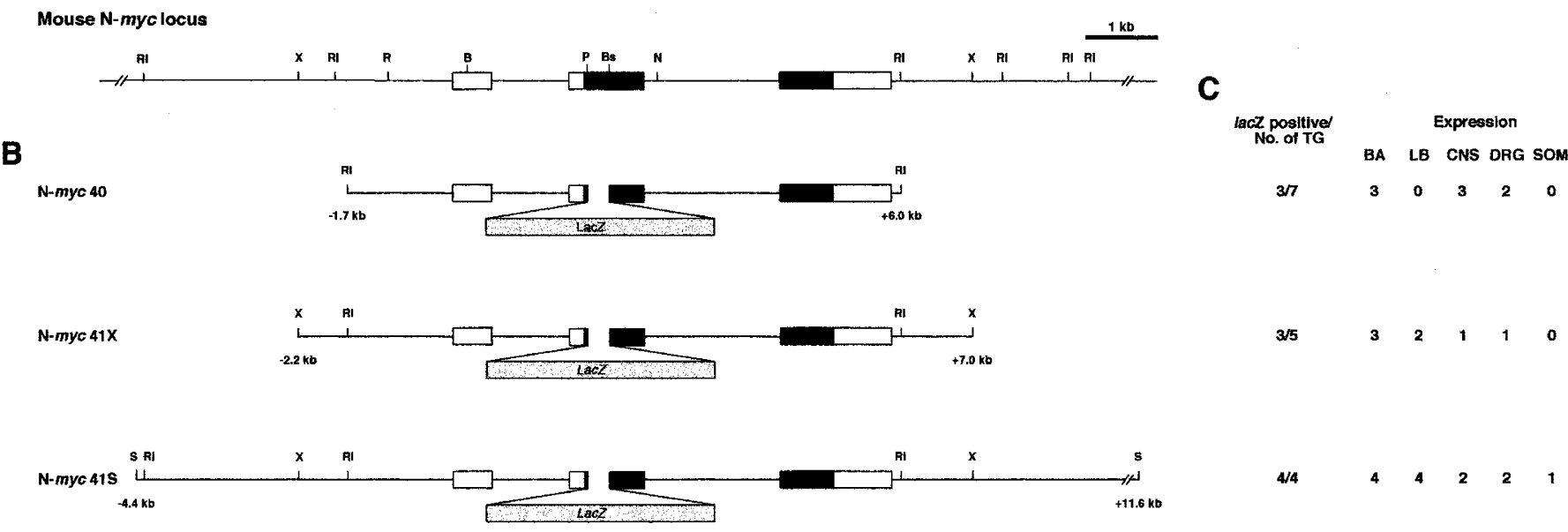

Figure 3. Characterization of the regulatory regions of the mouse N-myc gene in transgenic mouse embryos. Schematic representation of the mouse N-myc/lac Z constructs and their sites of expression from E8.5 to E11.5. A, structure of mouse N-myc gene, from which the various constructs werederived. Open boxes indicate transcribed regions and black boxes correspond to translated regions. $B$, diagram of the $\mathrm{N}-m y c / l a c \mathrm{Z}$ constructs used to generate the transgenic mice. The production of these constructs is described in the "Methods" section. $C$, summary of transgenic expression analysis. The first column represents the number of lacZ-expressing founders from the total number of transgenic founders obtained. The number of positively stained lines for each structure listed is indicated. $B A$, branchial arches; $D R G$, dorsal root ganglia; $L B$, limb buds; SOM, somites; B, BamHI; Bs, BssHI; N, NruI; P, PvuI; R, RsrII, RI, EcoRI, S, SalI, X, XbaI. 

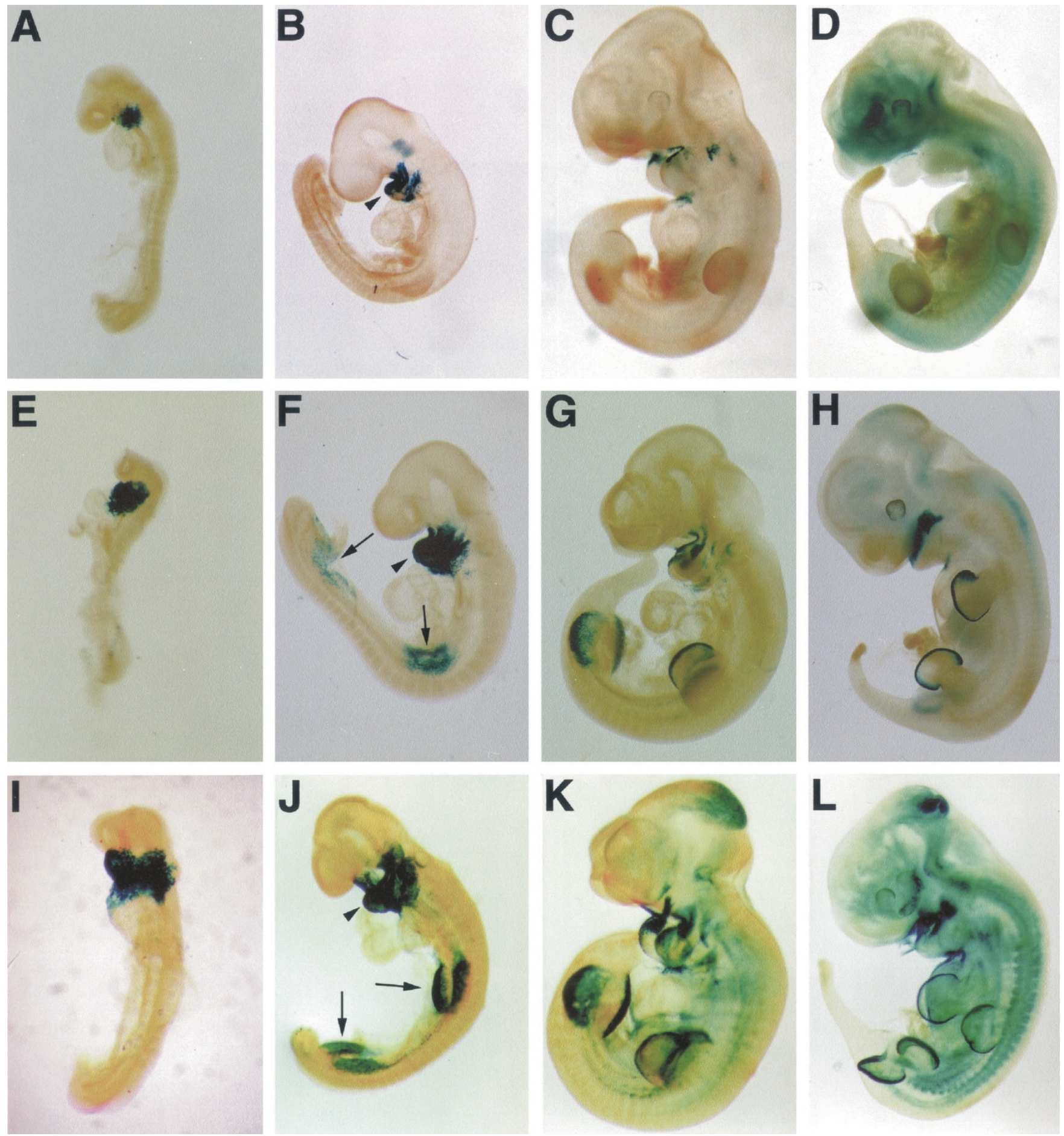

Figure 4. Developmental time course of $\beta$-galactosidase expression obtained with different $\mathrm{N}-m y c / l a c \mathrm{Z}$ constructs in transgenic embryos. $A-D$, construct $\mathrm{N}-m y c$ 40; $E-H$, construct N-myc $41 \mathrm{X} ; I-L$, construct N-myc $41 \mathrm{~S}$. Expression was analyzed at E8.5 (A, E, I), E9.5 (B, $F, J)$, E10.5 (C, G, K), and E11.5 (D, $H, L)$. Expression in branchial arches (arrowheads) and limb buds (arrows) is shown for E9.5 stage. Similar pattern of staining in branchial arches was observed for all three constructs, whereas expression in limb buds was restricted to longer constructs $\mathrm{N}-m y c 41 \mathrm{X}$ and N-myc $41 \mathrm{~S}(F-H, J-L)$.

$+6.0-\mathrm{kb}$ to $+7.0-\mathrm{kb}$ region (Fig. 3). The temporal expression of the N-myc 41X transgene in the limb buds mimicked the endogenous one (28). However, the tissue distribution did not correspond to the normal N-myc expression; N-myc transcripts are detected in the progression zone of the limb whereas transgene expression was restricted to the apical ectodermal region. Therefore, more regulatory sequences are needed to achieve cell-specific expression in the limb.
$\beta$-Galactosidase activity was never observed in the heart, and in only one instance in the somites. In the latter case, the expression was detected in the rostral part of the somites although normally $\mathrm{N}-m y c$ expression is confined to the caudal moiety (28). Because a unique transgenic line (1 of 16) presented ectopic X-gal staining in the somites, this may reflect the influence of the site of integration on the expression of the transgene. 
$\mathrm{N}-m y c$ mutant embryos die because of heart defects (15-17, 20). Therefore, absence of the ability of the N-myc regulatory regions to direct expression in the heart might explain the lack of rescue of the $\mathrm{N}-m y c$ mutant phenotype when a human $\mathrm{N}-m y c$ transgene was used. However, we cannot rule out the possibility that the appropriate control sequences were present in the human transgene but that the human N-Myc protein differs in its properties from the mouse protein. This latter possibility appears unlikely owing to the high levels of identity between both proteins (41). In addition, recent data have shown that despite a lesser degree of homology, the N-Myc protein can replace the c-Myc one in its function (3). Accumulating experimental evidence demonstrates that regulatory elements of important developmental genes are conserved during evolution. In that regard, we can hypothesize that the mouse $\mathrm{N}-m y c$ regulatory regions that will be identified from transgenic analyses will be similarly organized at the human $\mathrm{N}-m y c$ locus (47).

Characterization of murine $\mathrm{N}-m y c$ regulation has revealed several control elements, including two promoting regions located between positions $-980 \mathrm{bp}$ and $-797 \mathrm{bp}$, and positions $-279 \mathrm{bp}$ and $+108 \mathrm{bp}$, as well as an inhibiting sequence localized in the -860 -bp to -797 -bp region $(32,33)$. In addition, an orphan nuclear receptor element involved in the activation of $\mathrm{N}-m y c$ transcription by ROR $\alpha 1$ has been identified in the first intron of human and mouse N-myc genes (37). Moreover, in the human gene, sequences located in the exon 1 -intron 1 region were shown to be implicated in the regulation of tissue-specific expression of $\mathrm{N}-m y c(38,39,48)$.

Our findings provide evidence that these cis-acting elements known to regulate $\mathrm{N}-m y c$ gene expression in vitro are insufficient to drive its proper expression in vivo. They strongly suggest that important distal regulatory elements exist in the N-myc gene, although definitive proof awaits their identification.

Acknowledgments. We thank Drs. Lucie Jeannotte and Josée Aubin for critical comments on the manuscript, Drs. Kathryn Zimmerman and Frederick W. Alt for the TgN(hN1) transgenic mice and N-myc genomic clone, and Dorine Bernard, France Roy Marcelle Carter, and Michel Trembaly for skilled technical assistance.

\section{REFERENCES}

1. Alt FW, DePinho R, Zimmerman K, Legouy E, Hatton K, Ferrier P, Tesfaye A, Yancopoulos G, Nisen P 1986 The human myc gene family. Cold Spring Harb Symp Quant Biol 51:931-941

2. Galderisi U, Di Bernardo G, Cipollaro M, Peluso G, Cascino A, Cotrufo R, Melone MA 1999 Differentiation and apoptosis of neuroblastoma cells: role of $\mathrm{N}-m y c$ gene product. J Cell Biochem 73:97-105

3. Malynn BA, de Alboran IM, O'Hagan RC, Bronson R, Davidson L, DePinho RA, Alt FW $2000 \mathrm{~N}-m y c$ can functionally replace c-myc in murine development, cellular growth, and differentiation. Genes Dev 14:1390-1399

4. Grandori C, Eisenman RN 1997 Myc target genes. Trends Biochem Sci 22:177-181

5. Blackwood EM, Eisenman RN 1991 Max: a helix-loop-helix zipper protein that forms a sequence-specific DNA-binding complex with Myc. Science 251:1211-1217

6. Morgenbesser SD, DePinho RA 1994 Use of transgenic mice to study myc family gene function in normal mammalian development and in cancer. Semin Cancer Biol 5:21-36

7. Henriksson M, Luscher B 1996 Proteins of the Myc network: essential regulators of cell growth and differentiation. Adv Cancer Res 68:109-182

8. Aubry S, Charron J $2000 \mathrm{~N}-$ Myc shares cellular functions with c-Myc. DNA Cell Biol 19:353-364

9. Zimmerman K, Alt FW 1990 Expression and function of Myc family genes. Crit Rev Oncog 2:75-95
10. Hachitanda Y, Toyoshima S, Akazawa K, Tsuneyoshi M 1998 N-myc gene amplification in rhabdomyosarcoma detected by fluorescence in situ hybridization: its correlation with histologic features. Mod Pathol 11:1222-1227

11. Wimmer K, Zhu XX, Lamb BJ, Kuick R, Ambros PF, Kovar H, Thoraval D, Motyka S, Alberts JR, Hanash SM 1999 Co-amplification of a novel gene, NAG, with the $\mathrm{N}-m y c$ gene in neuroblastoma. Oncogene 18:233-238

12. Schwab M 1993 Amplification of N-myc as a prognostic marker for patients with neuroblastoma. Semin Cancer Biol 4:13-18

13. Wada RK, Seeger RC, Brodeur GM, Einhorn PA, Rayner SA, Tomayko MM, Reynolds CP 1993 Human neuroblastoma cell lines that express N-myc without gene amplification. Cancer 72:3346-3354

14. Tsuchida Y, Hemmi H, Inoue A, Obana K, Yang HW, Hayashi Y, Kanda N, Shimatake H 1996 Genetic clinical markers of human neuroblastoma with special reference to N-myc oncogene: amplified or not amplified? - an overview. Tumour Biol 17:65-74

15. Charron J, Malynn BA, Fisher P, Stewart V, Jeannotte L, Goff SP, Robertson EJ, Alt FW 1992 Embryonic lethality in mice homozygous for a targeted disruption of the $\mathrm{N}-m y c$ gene. Genes Dev 6:2248-2257

16. Sawai S, Shimono A, Wakamatsu Y, Palmes C, Hanaoka K, Kondoh H 1993 Defects of embryonic organogenesis resulting from targeted disruption of the N-myc gene in the mouse. Development 117:1445-1455

17. Stanton BR, Perkins AS, Tessarollo L, Sassoon DA, Parada LF 1992 Loss of N-myc function results in embryonic lethality and failure of the epithelial component of the embryo to develop. Genes Dev 6:2235-2247

18. Giroux S, Charron J 1998 Defective development of the embryonic liver in N-mycdeficient mice. Dev Biol 195:16-28

19. Moens CB, Auerbach AB, Conlon RA, Joyner AL, Rossant J 1992 A targeted mutation reveals a role for $\mathrm{N}-m y c$ in branching morphogenesis in the embryonic mouse lung. Genes Dev 6:691-704

20. Moens CB, Stanton BR, Parada LF, Rossant J 1993 Defects in heart and lung development in compound heterozygotes for two different targeted mutations at the N-myc locus. Development 119:485-499

21. Bates CM, Kharzai S, Erwin T, Rossant J, Parada LF 2000 Role of N-myc in the developing mouse kidney Dev Biol 222:317-325

22. Davis AC, Wims M, Spotts GD, Hann SR, Bradley A 1993 A null c-myc mutation causes lethality before 10.5 days of gestation in homozygotes and reduced fertility in heterozygous female mice. Genes Dev 7:671-682

23. Davis A, Bradley A 1993 Mutation of N-myc in mice: what does the phenotype tell us? Bioessays 15:273-275

24. Schmid P, Schulz WA, Hameister H 1989 Dynamic expression pattern of the myc protooncogene in midgestation mouse embryos. Science 243:226-228

25. Mugrauer G, Ekblom P 1991 Contrasting expression patterns of three members of the $m y c$ family of protooncogenes in the developing and adult mouse kidney. J Cell Biol 112:13-25

26. Hirning U, Schmid P, Schulz WA, Rettenberger G, Hameister H 1991 A comparative analysis of N-myc and c-myc expression and cellular proliferation in mouse organogenesis. Mech Dev 33:119-125

27. Hirvonen H, Makela TP, Sandberg M, Kalimo H, Vuorio E, Alitalo K 1990 Expression of the myc proto-oncogenes in developing human fetal brain. Oncogene 5:1787-1797

28. Kato K, Kanamori A, Wakamatsu Y, Sawai S, Kondoh H 1991 Tissue distribution of $\mathrm{N}-m y c$ expression in the early organogenesis periods of the mouse embryo. Dev Growth Differ 33:29-36

29. Downs KM, Martin GR, Bishop JM 1989 Contrasting patterns of myc and N-myc expression during gastrulation of the mouse embryo. Genes Dev 3:860-869

30. Stanton BR, Parada LF 1992 The N-myc proto-oncogene: developmental expression and in vivo site-directed mutagenesis. Brain Pathol 2:71-83

31. Mugrauer G, Alt FW, Ekblom P $1988 \mathrm{~N}-m y c$ proto-oncogene expression during organogenesis in the developing mouse as revealed by in situ hybridization. J Cell Biol 107:1325-1335

32. Imamura Y, Nakagawa T, Iguchi-Ariga SM, Ariga H 1993 Transcriptional regulation of the N-myc gene: identification of positive regulatory element and its double- and single-stranded DNA binding proteins. Biochim Biophys Acta 1216:273-285

33. Imamura Y, Iguchi-Ariga SM, Ariga H 1992 The upstream region of the mouse $\mathrm{N}-m y c$ gene: identification of an enhancer element that functions preferentially in neuroblastoma IMR32 cells. Biochim Biophys Acta 1132:177-187

34. Hiller S, Breit S, Wang ZQ, Wagner EF, Schwab M 1991 Localization of regulatory elements controlling human MYCN expression. Oncogene 6:969-977

35. Wada RK, Seeger RC, Reynolds CP, Alloggiamento T, Yamashiro JM, Ruland C, Black AC, Rosenblatt JD 1992 Cell type-specific expression and negative regulation by retinoic acid of the human N-myc promoter in neuroblastoma cells. Oncogene 7:711-717

36. Xu L, Meng Y, Wallen R, DePinho RA 1995 Loss of transcriptional attenuation in $\mathrm{N}-m y c$ is associated with progression towards a more malignant phenotype. Oncogene $11: 1865-1872$

37. Dussault I, Giguere V 1997 Differential regulation of the N-myc proto-oncogene by ROR alpha and RVR, two orphan members of the superfamily of nuclear hormone receptors. Mol Cell Biol 17:1860-1867

38. Tai KF, Rogers SW, Pont-Kingdon G, Carroll WL 1999 Definition of the human $\mathrm{N}-m y c$ promoter region during development in a transgenic mouse model. Pediatr Res 46:255-262

39. Sivak LE, Pont-Kingdon G, Le K, Mayr G, Tai KF, Stevens BT, Carroll WL 1999 A novel intron element operates posttranscriptionally to regulate human $\mathrm{N}-m y c$ expression. Mol Cell Biol 19:155-163

40. Zimmerman K, Legouy E, Steward V, DePinho RA, Alt FW 1990 Differential regulation of the N-myc gene in transfected cells and transgenic mice. Mol Cell Biol 10:2096-2103 
41. DePinho RA, Legouy E, Feldman LB, Kohl NE, Yancopoulos GD, Alt FW 1986 Structure and expression of the murine N-myc gene. Proc Natl Acad Sci USA 83:1827-1831

42. Charron J, Malynn BA, Robertson EJ, Goff SP, Alt FW 1990 High-frequency disruption of the N-myc gene in embryonic stem and pre-B cell lines by homologous recombination. Mol Cell Biol 10:1799-1804

43. Vogelstein B, Gillespie D 1979 Preparative and analytical purification of DNA from agarose. Proc Natl Acad Sci USA 76:615-619

44. Hogan B, Beddington R, Costantini F, Lacy E 1994 Manipulating the Mouse Embryo: a Laboratory Manual, 2 Ed. Cold Spring Harbor Laboratory Press, Cold Spring Harbor, NY, pp 217-252

45. Larochelle C, Tremblay M, Bernier D, Aubin J, Jeannotte L 1999 Multiple cis-acting regulatory regions are required for restricted spatio-temporal Hoxa5 gene expression. Dev Dyn 214:127-140

46. Woodruff KA, Rosenblatt JD, Moore TB, Medzoyan RH, Pai DSM, Noland JL, Yamashiro JM, Wada RK 1995 Cell type-specific activity of the N-myc promoter in human neuroblastoma cells is mediated by a downstream silencer. Oncogene 10:1335-1341

47. Graham A 2000 The evolution of the vertebrates - genes and development. Curr Opin Genet Dev 10:624-628

48. Woodruff KA, Rosenblatt JD, Moore TB, Medzoyan RH, Pai DS, Noland JL, Yamashiro JM, Wada RK 1995 Cell type-specific activity of the N-myc promoter in human neuroblastoma cells is mediated by a downstream silencer. Oncogene 10:1335-1341 